\title{
Effect of Imidacloprid and Triadimefon on microbial phosphatase, protease and urease enzyme activities in tomato (Lycopersicon esculentum sp.) cultivated soil
}

\section{B. Vineela Deborah* and R.J aya M adhuri}

Department of Applied Microbiology, Sri Padmavathi Women's University, Tirupati-517502 (Andhra Pradesh), INDIA *Corresponding author. Email: vinnideborah@yahoo.com

Received: April 3, 2013; Revised received: August 2, 2013; Accepted: August 5, 2013

\begin{abstract}
The laboratory studies were conducted to resolute the effects of Imidacloprid (insecticide) and Triadimefon (fungicide) singly and in combination on enzymatic activities of soil microorganisms in tomato cultivated soils at different concentrations of $0.2,0.5$ and $0.7 \mathrm{~kg}$ per hectare. It was observed that phosphatase, protease and urease activities were elevated noteworthy at $0.5 \mathrm{~kg}$ per hectare after 10 days of incubation. At lower concentration the activities of these enzymes showed no significant difference from that of control. The combination of the two pesticides led to a pronounced decline of phosphatase and protease enzyme activities at higher concentration. Triadimefon had no effect on urease activity at low concentrations whereas at 0.5 and 0.7 concentrations there was a significant increase when compared to control.
\end{abstract}

Keywords: Imidacloprid, Soil enzymes, Tomato cultivated soil, Triadimefon

\section{INTRODUCTION}

Modern agriculture depends on wide variety of synthetically produced chemicals including insecticides, fungicides, herbicides and other pesticides (Zhang et al., 2011). When a synthetic pesticide is released into the environment, about $0.1 \%$ is reaching the target organism, while the remaining $0.99 \%$ interferes local metabolism or enzymatic activities, and also affects human health by entering into the food chain which has raised considerable public concern (Ramudu et al., 2011). These pesticides eventually reach the soil and may affect the growth of soil microbial community (Omar and Abdel Sater, 2001) Although these pesticides have been restrictively used, still bioaccumulation is found in soils. Thus, it is required to estimate soil biological responses to the pesticides in terms of soil enzyme activities. When compared to the enzymes from different sources, soil enzymes commonly show particular and peculiar feature (Nasreen et al., 2012) in terms of energy transfer, nutrient cycling, environmental quality and crop productivity. Tomato (Lycopersicum esculentum) is a major vegetable crop in Madanapalle, Chittoor district of Rayalaseema region, Andhra Pradesh, India. It is grown in abundance in the district with an average of 35,000 acres producing 3 to 4 lakh million tons per annum and extensively used in fruit processing industries.Pesticides like Imidacloprid and Triadimefon are commonly used for pest control in tomato crop nowadays. Imidacloprid is a systemic nicotinic compound with a potent insecticidal activity against a wide range of pests of vegetable crops (Nasreen et al., 2012) and Triadimefon is a systemic triazole foliar fungicide with a good fungicidal activity (Extension Technology Network, Cornell university). Despite of their potent role in pest control, there is no information available on the interaction effects of imidacloprid and triadimefon in tomato cultivated fields of Madanapalle. Among the various enzymes, phosphatase, protease and urease play important role. Phosphatases mineralize organic phosphorus to inorganic phosphorous. Protease catalyzes the hydrolysis of proteins to poly peptides and oligo peptides to amino acids (Kandeler, 1989). Urease catalyzes the hydrolysis of urea to $\mathrm{CO}_{2}$ and $\mathrm{NH}_{3}$. Hence, it is aimed to study the influence of the pesticides singly and in combination on the soil microbial phosphatase, protease and urease enzyme activities in red soil of tomato crop, L.esculentum.

\section{MATERIALS AND METHODS}

Soil sampling and analysis: Red soil was collected randomly from different sites of tomato cultivated fields of Madanapalle, Chittoor district of Andhra Pradesh, India near the rhizosphere zone (a zone of increased microbial and enzyme activity where soil and root make contact) using a trowel at a depth of 0-12 centimeters and mixed thoroughly to prepare a homogenate composite sample, air dried then passed through $2 \mathrm{~mm}$ sieve to remove plant material and other debris. This soil was brought to the laboratory, sealed in bags and stored at $4^{\circ} \mathrm{C}$ prior to analysis. The soil was analyzed for various physico- 
chemical parameters viz., sand,silt,clay, $\mathrm{P}^{\mathrm{H}}$,water holding capacity etc. and soil organic matter estimation by dichromate digestion (Walkley and Black, 1934), Microkjeldahl method for nitrogen estimation (Jackson, 1971) was done. Unamended and pesticide amended soil samples were slightly alkaline with a $\mathrm{pH}$ ranging from 78.2 and they were having a medium content of organic matter, soil moisture and nitrogen content. The microbial population was same in untreated and triadimefon treated soil whereas there is slight decrease in the number of microbial population in imidacloprid amended soil.

Pesticides used: The selected pesticides imidacloprid and triadimefon were purchased from Saraswathi agrochemicals, Jammu \& Kashmir, and Bayer Crop Sciences, Himatnagar, India.The chemical formula and IUPACs name of these pesticides are as follows:

Imidacloprid: The chemical formula of imidacloprid is $\mathrm{C}_{9} \mathrm{H}_{10} \mathrm{ClN}_{5} \mathrm{O}_{2}$ and the IUPAC name is (E)-1-(6-chloro-3pyridylmethyl)- $\mathrm{N}$-nitroimidazolidin-2-ylideneamine.It is also known as nicotinamide and a common insecticide.

Triadimefon : The chemical formula of triadimefon (Triazole) is $\mathrm{C}_{14} \mathrm{H}_{16} \mathrm{ClN}_{3} \mathrm{O}_{2}$ and the IUPAC name of it is 1(4-chlorophenoxy)-3,3-dimethyl-1-(1H-1,2,4-triazol-1yl)butan-2-one.It is a common fungicide.

Soil incubation: 5, 2 and $1 \mathrm{~g}$. of soil samples were taken in test tubes $(25 \times 150 \mathrm{~mm})$ for the assay of phosphatase, protease and urease activities respectively. Stock solutions from selected pesticides were added at the rate of $25,50,75 \mu \mathrm{g}$ per gram soil, which are equivalent to field application rate of 250,500 and 750 gms per hectare respectively. Soil samples without pesticide application served as controls. Soil samples were mixed thoroughly for uniform distribution. Duplicates were maintained at $28 \pm 40^{\circ} \mathrm{C}$ with $60 \%$ water holding capacity (WHC) throughout the experimental period.

Assay of enzymes: The method employed for assay of phosphatase was developed by Tabatabai (1983). Soil samples were transferred to Erlenmeyer flasks and treated with $0.2 \mathrm{ml}$ toluene to arrest the enzyme activity. To this $4 \mathrm{ml}$ of 0.1 M malate buffer, $2 \mathrm{ml}$ of $0.03 \mathrm{M}$ para nitro phenol (PNP) were added, mixed thoroughly, incubated for 3 hours at $37^{\circ} \mathrm{c}$, and then kept in ice. Then the contents were filtered by passing through Whatmann no. 1 filter paper. To the filtrate, $1 \mathrm{ml}$ of $5 \mathrm{mM} \mathrm{CaCl}_{2}$ and $4 \mathrm{ml}$ of $0.5 \mathrm{M}$ $\mathrm{NaOH}$ were added and mixed uniformly. The yellow color developed was read at $405 \mathrm{~nm}$ in a spectrophotometer.

Ladd and Buttler (1972) method was employed to assay the activity of protease. Soil samples were collected in sterile Erlenmeyer flasks. To these samples, $10 \mathrm{ml}$ of Tris base buffer with $1 \%$ sodium caseinate was added .No casein was added to the control. Then $4 \mathrm{ml}$ of TCA was added to these samples and centrifuged. To the filtrate, $3 \mathrm{ml}$ of $1.4 \mathrm{M} \mathrm{Na}_{2} \mathrm{CO}_{3}, 1 \mathrm{ml}$ Folin Ciocalteu's reagent (FC) were added. The color developed was read at $760 \mathrm{~nm}$ in a Spectrophotometer.

After 10 days of incubation, duplicate soil samples were withdrawn and urease enzyme activity was assayed using standard method of Fawcett (1960). The soil samples were transferred to Erlenmeyer flasks and $1 \mathrm{ml}$ of $3 \%$ urea, $2 \mathrm{ml}$ of $0.1 \mathrm{M}$ sodium phosphate buffer were added and kept for 30 minutes of incubation at $37^{\circ} \mathrm{C}$, then cooled at $4^{\circ} \mathrm{C}$ for 10 minutes to stop enzyme activity. Then $10 \mathrm{ml}$ of $2 \mathrm{M}$ $\mathrm{KCl}$ was added to the soil samples and centrifuged. $4 \mathrm{ml}$ of filtrate was collected. To this filtrate, $5 \mathrm{ml}$ of sodium nitroprusside and $3 \mathrm{ml}$ of $0.02 \mathrm{M}$ hypochlorite solution were added and kept in dark room for 30 minutes. Yellow color developed was assayed at $630 \mathrm{~nm}$ using a Spectrophotometer.

\section{RESULTS}

Phosphatase activity in tomato, L. esculentum cultivated soil showed a variable pattern in response to pesticides and their combination after 10 days of incubation. Enzyme activity increased at all the concentrations except at higher concentrations of Triadimefon and Imidacloprid. The combination of these two showed maximum

Table 1. Physico-chemical and microbiological properties of the soil.

\begin{tabular}{lccc}
\hline Properties & Untr eated soil & $\begin{array}{c}\text { Soil treated with } \\
\text { imidacloprid }\end{array}$ & $\begin{array}{c}\text { Soil treated with } \\
\text { triadimefon }\end{array}$ \\
\hline Sand \% & 70 & 72 & 72 \\
Silt \% & 11 & 12 & 16 \\
Clay \% & 5.0 & 4.8 & 4.8 \\
pH & 8.46 & 7.89 & 8.0 \\
Water holding capacity & 0.4 & 0.4 & 0.4 \\
(WHC) ml.g-1 soil \% & & & \\
Organic matter \% & 0.44 & 0.38 & 0.27 \\
Total nitrogen content & 0.04 & 0.19 & 0.07 \\
Microbial content & & & \\
(in CFU/ml) & & 9 & 11 \\
Bacteria & 11 & 7 & 10 \\
Fun gi & & & \\
\hline
\end{tabular}




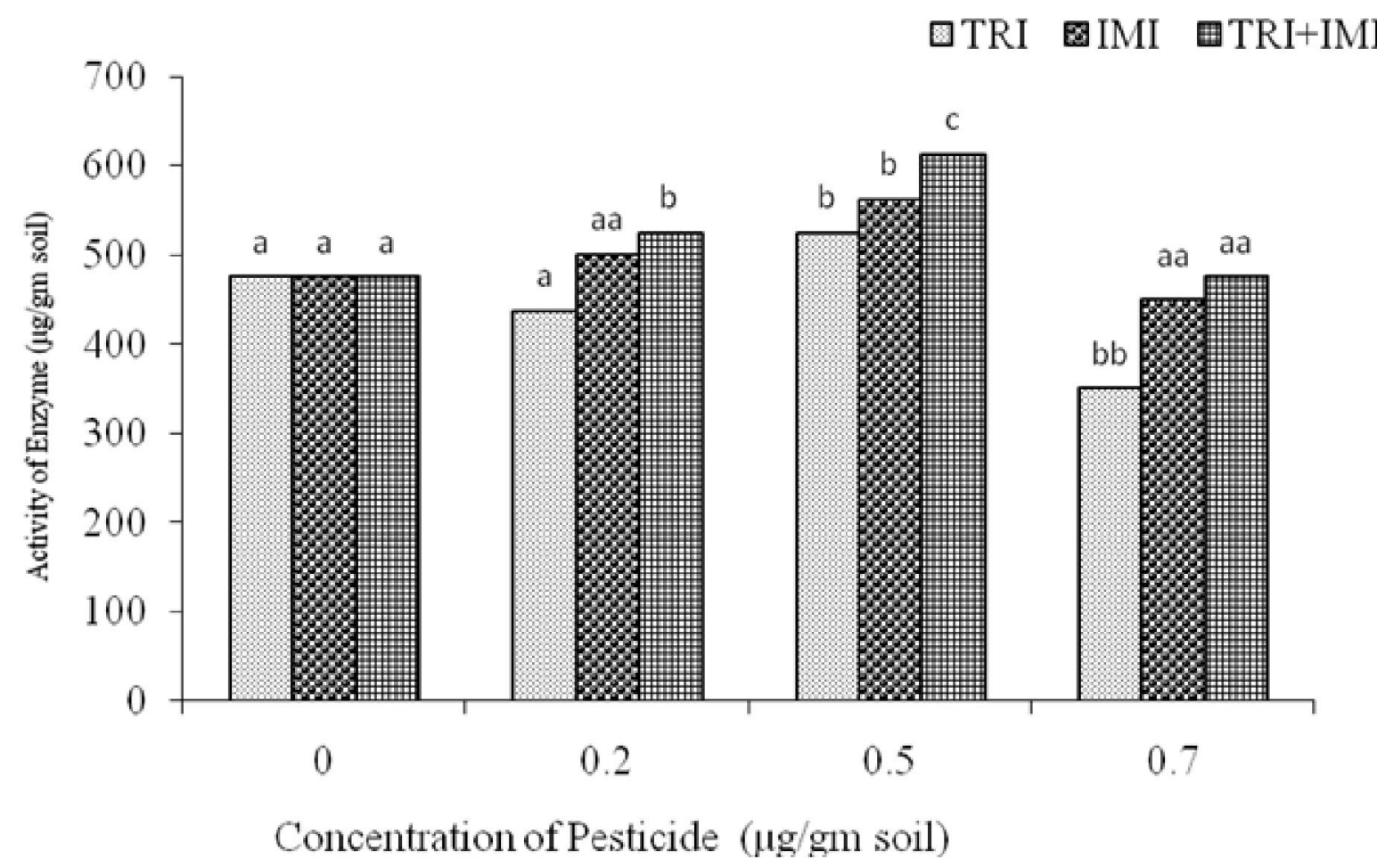

Fig.1. Showing the phosphatase enzyme activity.TRI-Triadimefon, IM I-Imidacloprid, TRI+IMI-Triadimefon+Imidacloprid. Bars marked by the same letter are not significantly different $(P<0.05)$ from each other according to $D$ M $R$ ( $D$ uncan's multiple range) test.

enhancement of enzyme activity at field application rate (FAR) and there was much difference in the activity compared to control (Fig. 1).

The insecticide, imidacloprid showed much decrease in protease enzyme activity at high concentration. Interestingly this pesticide showed maximum enhancement of enzyme activity at field application rate (FAR) than the others. The combination of the pesticides was stimulatory at all the concentrations. Triadimefon also had a noticeable effect at field application rate (Fig.2). The urease activity was increased at field application rate (FAR) in all the samples treated with triadimefon, imidacloprid and the combination of the two pesticides. There was a significant stimulation of urease activity by the application of triadimefon at field application rate. With imidacloprid and the combination of two pesticides, there was a dramatic decrease both at the lower and higher concentrations in comparison to the control (Fig.3).

\section{DISCUSSION}

The tomato, L.esculentum cultivated soil samples were slightly alkaline with a $\mathrm{pH}$ ranging from 7-8.2 and they were having a medium content of organic matter, soil moisture and nitrogen content. The microbial population was same as that in untreated and triadimefon treated soil whereas there is slight decrease in the number of microbial population in imidacloprid amended soil.Persistence of pesticide residues in the soil may have a significant effect on soil microbial functions such as the activity of enzymes which are directly related to soil health, fertility and also to the removal of contaminants. Among the soil enzymes, phosphates, proteases and urease play an important role. Phosphatases mineralize organic phosphorus to inorganic phosphorous (Omar and Abdel Sater, 2001). Phosphatases play a key role in $P$ mineralization in soil and it is important to know the response of these enzyme activities to the changes in the environmental factors, agricultural management and pollution (Nannipieri et al., 2011). The hydrolysis of proteins, first phase in mineralization of soil organic nitrogen is dependent on enzymes, which are synthesized by plants and soil microorganisms. Protease plays a key role in this step Urease plays a key role in hydrolysis of urea into $\mathrm{NH}_{4+}$ ions and $\mathrm{CO}_{2}$ (Tabatabai, 1983) and influences the availability of plant utilizable forms of nitrogen in soils with nitrogen carriers especially urea.

The present study revealed that there was a stimulatory effect in relation to protease activity, which was also supported by Jaya madhuri and Rangaswami (2009) . Protease activity was accelerated up to field application rate (FAR) of imidacloprid, triadimefon and their combination. Kumar and Prakash (1993) demonstrated that two herbicides, Thiobencarb and butachlor reduced protease activity at $25 \mathrm{ppm}$ but increased it at $75 \mathrm{ppm}$. On the other hand, Trifuralin and Pendimethrin progressively reduced the protease activity with increasing concentration (Pahwa and Bajaj, 1999)

The present results of urease showed significant stimulation by fungicide, Triadimefon treatment. Addition of insecticide at field application rate (FAR) significantly 


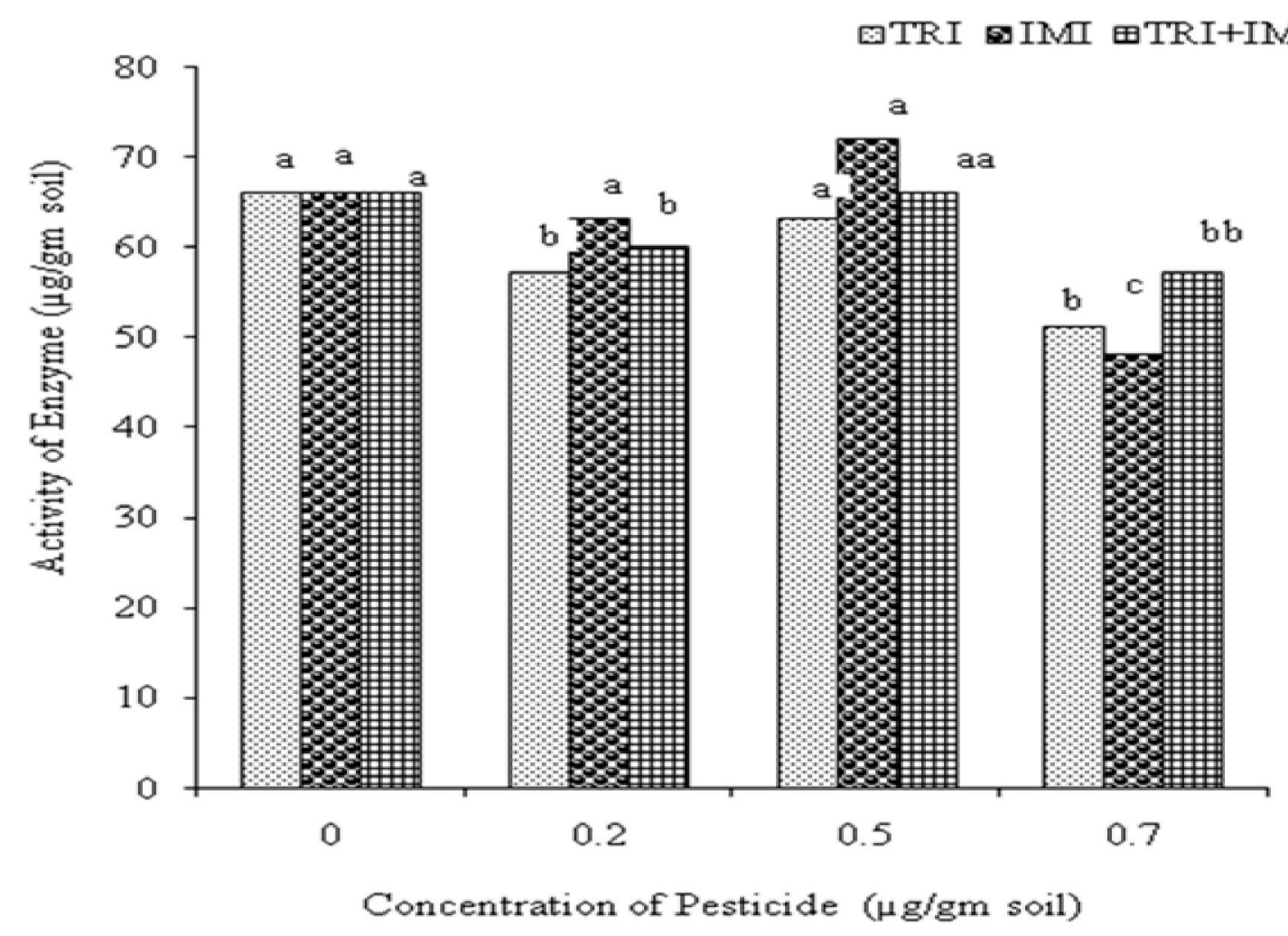

Fig. 2. Showing protease activity. TRI-Triadimefon, IMI-Imidacloprid, TRI+IMI-Triadimefon+Imidacloprid. Bars marked by the same letter are not significantly different $(P<0.05)$ from each other according to $D M R$ ( $D$ uncan's multiple range) test.

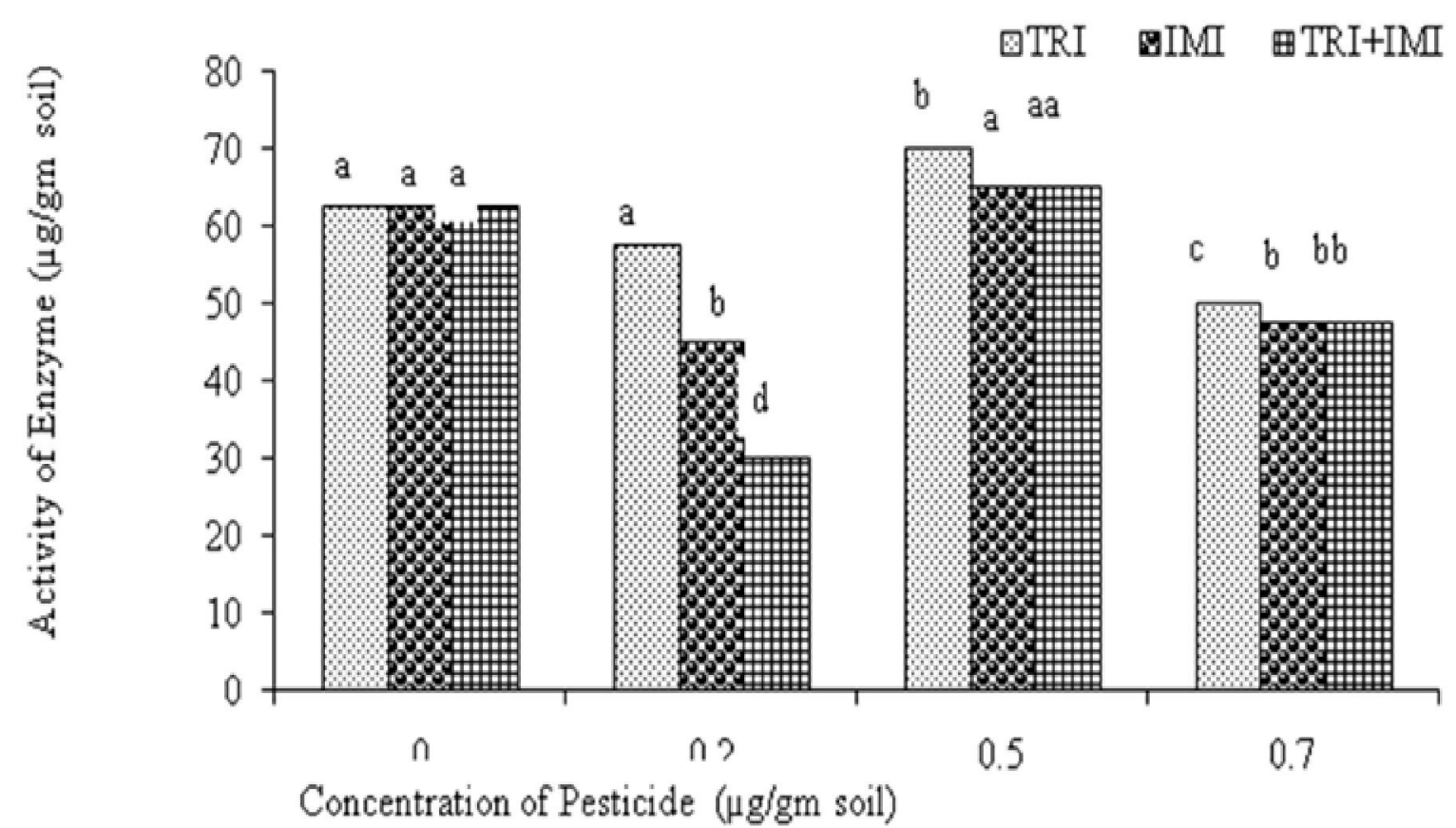

Fig.3. Showing urease activity. TRI-Triadimefon, IMI-Imidacloprid, TRI+IMI-Triadimefon+I midacloprid. Bars marked by the same letter are not significantly different $(P<0.05)$ from each other according to $D M R$ ( $D$ uncan's multiple range) test.

increased urease activity at 10 days incubation. The activity was inhibited at higher concentration. Sannino and Gianfreda (2001) observed that urease was relatively unaffected by several pesticides such as Glyphosate and Paraquat. When the treatment effects of diazinon or imidacloprid were compared for the control there were no significant positive or negative effects of insecticides (Ingram et al., 2005). The present studies showed pronounced effect of phosphatase at field application rate by the combination of the two pesticides. 


\section{Conclusion}

It was concluded that the activities of three enzymes were not affected by the pesticides when applied at the recommended levels (FAR) to the agriculture system. The inhibition of enzymatic activities especially at higher concentration in soils indicated reduced microbial activity. It is attributed to the influence of added chemicals or their metabolites formed in soils during incubation.

\section{ACKNOWLEDGMENTS}

I express my gratitude to Dr. R. Jaya Madhuri, Department of Applied Microbiology, Sri Padmavathi Women's University, Tirupati, Andhra Pradesh., for suggesting the research problem, constant encouragement and guidance.

\section{REFERENCES}

Fawcett J. and Scot, J.E. (1960). A rapid and precise method for determination of urea. J. Clin. Path., 13:156-159

Ingram, C.W., Coyne, M.S. and Williams, D.W. (2005). Effects of commercial diazonin and imidacloprid on microbial urease activity in soil and sod. J ournal of E nvironmental Q uality, 34:1573-1580

Jackson, M.L. (1971). Soil chemical analysis. Prentice Hall. New Delhi.

Jaya Madhuri, R. and Rangaswamy.V. (2009). Effect of selected insecticides on microbial activities of dehydrogenase, protease and urease in groundnut soils. Indian J ournal of Environmental Sciences, 13(1):1-8.

Kumar, J.K. and Prakash, J. (1993). Persistence of thiobencarb and butachlor in soil incubated at different temperatures. In: Integrated weed management for sustainable agriculture. Proceedings of Indian Society of Weed Science International Seminar. Hisar, India. pp. 123-124.

Kandeler, E. (1989). Protease in soils and methods from the determination of their activity. Soils and Fertilizers, 6:68-72
Ladd, J.N. and Butler, J.H.A. (1972). Short-term assays of soil proteolytic enzyme activities using proteins and dipeptide derivatives as substrates. Soil Biol. Biochem., 4: 19-30.

Nannipieri, P., Giagnoni,L., Landi,L., and Renella,G. (2011). Role of Phosphatase Enzymes in Soil. Soil Biology, 100(2): 215-243.

Nasreen, C., Jaffer Mohiddin, G., Srinivasulu, M., Rekhapadmini, A., Ramanamma,P., and Rangaswamy, V. (2012). Interaction effects of insecticides on enzyme activities in black clay soil from groundnut (Arachis hypogeal.L.) fields). E nvironmental Research, Engineering and $\mathrm{M}$ anagement. 31(2). 21-28.

Omar, S.A. and Abdel Sater, M.A. (2001). Microbial populations and enzyme activities in soil treated with pesticides. Water, Air and Soil Pollution, 127(1-4): 49-63.

Pahwa, S.K. and Bajaj, K. (1999). Effects of pre-emergence Herbicides on the activity of á- amylase and protease enzyme during germination in Pigeonpea and Carpetweed. Indian J ournal of Weed Science,31(3-4):148-150.

Ramudu, A.C., Madakka, M., Srinivasulu, M. (2011). Impact of fungicides chlorothalonil and propiconazole on microbial activities in groundnut (Arachis hypogeal L.)soils.ISRN M icrobiology, Volume 2011 (2011), Article ID 623404.

Sannino, F. and Gianfreda, L. (2001). Pesticide influence on soil enzyme activities. Chemosphere, 45: 417 -425.

Tabatabai (1983). Soil enzymes, Methods of soil analysis. Part 2. Microbiological and biochemical properties. Soil. Biol. Biochem 15:403-408, 1983); Soil Science Society of America (1994), Madison, pp 775-833.

Walkley, A. and Black, I.A. (1934). An examination of the degtjareff method for determining soil organic matter and a proposed modification of the chromic acid titration method. Soil Sci., 37: 29-38.

Zhang WenJun, FuBin Jiang and JianFeng Ou. ( 2011). Methods of soil and agro chemistry analysis. Chinese Agricultural Science and Technology Press, Beijing (in Chinese). 156 No tillage affects soil enzymes kinetics. 